MAGDALENA WAŁACHOWSKA

Akademia Pedagogiki Specjalnej im. M. Grzegorzewskiej

Warszawa

Forum Pedagogiczne

2017/1

Wpłynęło: 23.01.2017

Zatwierdzono do druku: 29.03.2017

DOI: $10.21697 / \mathrm{fp} .2017 .1 .14$

\title{
WIZERUNEK SPOŁECZNY MACIERZYŃSTWA KOBIET Z NIEPEŁNOSPRAWNOŚCIĄ
}

Streszczenie: Celem artykułu jest przedstawienie macierzyństwa jako roli społecznej kobiety z niepełnosprawnością. Na wstępie zdefiniowano pojęcie roli społecznej, relacji społecznej, systemu społecznego oraz opisano mechanizm wzorowania kulturowego. Pierwsza część artykułu dotyczy macierzyństwa jako fundamentalnej roli społecznej kobiety. Przedstawione jest ono w perspektywie historycznej oraz tendencji ponowoczesnych przy równoczesnym nawiązaniu do potrzeb i powinności kojarzonych społecznie z tą rolą. W części drugiej poruszono kwestię wizerunku społecznego macierzyństwa kobiet z niepełnosprawnością. W trzeciej natomiast opisano bariery fizyczne, psychiczne, kulturowe i infrastrukturalne utrudniające podjęcie decyzji o macierzyństwie przez kobiety niepełnosprawne. Podsumowanie stanowią argumenty świadczące o pozytywnym znaczeniu rehabilitacyjnym obecności rodziny i macierzyństwa w życiu kobiet z niepełnosprawnością.

Słowa kluczowe: macierzyństwo, rola społeczna, kobieta z niepełnosprawnością.

\section{Wstęp}

Najistotniejszymi typami interakcji społecznych, jakie zachodzą pomiędzy jednostkami i grupami osób, są współdziałanie społeczne oraz konflikt społeczny. Interakcję pomiędzy dwojgiem osób nazywamy relacją społeczną. Większe społeczności tworzą analogicznie systemy społeczne, w których poszczególne jednostki, grupy oraz społeczeństwa odgrywają przyjęte i przypisane im role społeczne (Znaniecki 2011). Rola społeczna to „mający określoną strukturę system wymogów związanych z określoną pozycją społeczną. Jest to działający na jednostkę z zewnątrz system ułatwień i hamulców regulujących jej funkcjonowanie jako osobowości" (Kowalski 1986, s. 301). System społeczny powstanie, jeśli członkowie tego systemu będą współdziałać, a pomiędzy niektórymi z nich zawiążą się relacje społeczne. Człowiek może uczestniczyć jednocześnie w wielu różnych relacjach społecznych, odgrywając jednocześnie kilka ról społecznych na potrzeby otaczających go kręgów osób, które go akceptują i współdziałają z nim. Fundamentalnym 
warunkiem, który jednostka powinna wypełnić, aby odnieść sukces w realizacji określonej roli społecznej, jest wzorowanie kulturowe. Osoba, która pragnie pełnić określoną rolę społeczną, powinna stosować się do obowiązujących wzorów zachowań, które wiązane są kulturowo z daną rolą. Robi to jednak we właściwy wyłącznie dla siebie, twórczy sposób, sprawiając, iż pełniona przez nią rola jest jedyna w swoim rodzaju, choć jednocześnie jedna z wielu podobnych (Znaniecki 2011). Jedną z fundamentalnych, pierwotnych ról społecznych jest macierzyństwo.

\section{Macierzyństwo jako rola społeczna}

Macierzyństwo jest stanem oczywistym, naturalnym i pozytywnie wartościowanym społecznie (Górnikowska-Zwolak 2004). Według polskiej terminologii matka to „kobieta, która urodziła dziecko i zwykle je wychowuje” (Uniwersalny słownik języka polskiego 2003, s. 585). Słowo „matka” posiada wiele różnobarwnych znaczeń. Można je rozumieć w sensie macierzyństwa biologicznego, a więc stanu wydania na świat potomstwa lub macierzyństwa zastępczego - wydania na świat dziecka innym rodzicom $z$ ich materiału genetycznego bądź sprawowania pieczy rodzicielskiej w zastępstwie matki biologicznej. Potocznie matka utożsamiana jest z naturą (matka natura), sprawowaniem rządów (królowa matka), ojczyzną (matka ojczyzna) lub symbolem kobiecości, patriotyzmu i ogniska domowego (Matka Polka). Atrybutem matki jest czynność zwana macierzyństwem, określana jako „bycie matką i związane z tym uczucia, doznania, powinności” (Uniwersalny słownik języka polskiego 2003, s. 523).

Historyczny „archetyp matki w tradycji europejskiej wywodzi się od starożytnych Greków i Rzymian" (Bartkowiak 2015). Ówcześnie matka była postrzegana jako uosobienie standardów moralności i podstawa rodziny. Jej życie związane było z wykonywaniem zajęć gospodarstwa domowego i wychowaniem najmłodszych dzieci. Występowała jako pani domu i matka rodziny, będąc odsuniętą formalnie od spraw państwowych. W czasach średniowiecznych ogólna sytuacja matki i dziecka uległa pogorszeniu. Wychowanie nabrało zasadniczego, formalnego i praktycznego charakteru ze względu na swój stanowy charakter. Powszechną praktyką było wychowanie w obcym domu, co wiązało się z bardzo wczesnym opuszczeniem domu rodzinnego przez dziecko (zwłaszcza chłopców) w celu nauki zawodu. Rozłąka z matką następowała wówczas praktycznie na zawsze. Macierzyństwo nie przedstawiało większej wartości i zyskało miano niespełnionego, odebranego. Okres odrodzenia pozwolił macierzyństwu narodzić się na nowo. Zaczęto doceniać jego walory, czego wyrazem było podkreślanie wartości naturalnego karmienia, o którym pisał Sebastian Petrycy (1554-1626), wybitny polski lekarz, profesor medycyny w Akademii Krakowskiej: „lepiej jest, aby matka piersiami swemi karmiła dziecię niźli przez mamki [...] bo pokarm matczyn, abo podobny matce nazdrowszy jest dziecięciu" (Bartkowiak 2015, s. 282; za: Żołądź-Strzelczyk 2002, s. 53). Aspekt naturalnego karmienia miał wzmacniać więź fizyczną i emocjonalną pomiędzy 
matką a dzieckiem oraz wzmagać odpowiedzialność matki za jego wychowanie. Macierzyństwo zyskało jeszcze mocniejszą pozycję w epoce oświecenia dzięki Janowi Jakubowi Rousseau (1712-1778) oraz Johanowi Heinrichowi Pestalozziemu (1746-1827), według których sensem macierzyństwa była miłość do dziecka oraz mądre czuwanie przy nim poprzez planowe, naturalne wychowanie, zgodne z wyznaczonym celem. Pragmatyzm pozytywizmu upatrywał w macierzyństwie „ostoję biologicznego trwania gatunku i pomyślności społecznej" (Bartkowiak 2015, s. 288). Zainteresowanie społeczną stroną macierzyństwa poskutkowało w pierwszej połowie XIX wieku presją wywieraną na systematyczne przygotowanie rodziców do pełnienia obowiązków rodzicielskich poprzez odbywanie kursów z zakresu fizjologii i psychologii. Rodzice mieli być przygotowywani do roli wychowawców. Wizerunek macierzyństwa zmieniał się przez lata, ewoluując od koncepcji natury biologicznej do coraz bardziej świadomego pojmowania i systemowego rozumienia obowiązków matczynych.

Według Lidii Marszałek (2006) macierzyństwo, w wybranych kręgach kulturowych, określane jest mianem największej roli społecznej kobiety. „Urodzenie się kobietą przesądza - we wszystkich kulturach, miejscach i czasach - o biografii i możliwościach życiowych jednostki” (Gromkowska-Melosik 2013, s. 33) i oznacza predyspozycję do bycia matką, co ostatecznie wiąże się z doznawaniem różnorodnych emocji, koniecznością podejmowania określonych powinności na różnych etapach życia dziecka oraz posiadaniem przywilejów, które budują kobiecą tożsamość. Naturalną konsekwencją macierzyństwa jest pojawienie się pierwotnej i podstawowej relacji społecznej, jaką jest układ matka-dziecko. Florian Znaniecki (2011), opisując tę relację, podaje jej następujące cechy: powszechność (występowanie w społecznościach ludzkich), pierwotność (pierwsza relacja pojawiająca się w życiu człowieka), dynamika (stan tej relacji zmienia się w zależności od etapu życia dziecka), uwzorowanie (istnienie społecznych oczekiwań dotyczących sposobu realizacji tej relacji) oraz elementarność (relacja ta jest integralną częścią rodziny jako grupy społecznej). Macierzyństwo jest w literaturze przedmiotu opisywane w charakterze potrzeby lub powinności (Marszałek 2006), inaczej doświadczenia lub instytucji (Bielecka-Prus, Kruk 2014).

Potrzeba macierzyństwa jest wypadkową cech biologicznych i psychicznych kobiety, które w sposób wyjątkowy predestynują ją do podjęcia obowiązków matczynych. Anna Karczewska (2010; za: Szarzyńska 2005, s. 50), analizując obraz ról kobiet w przekazach medialnych, przedstawiła kilka komponentów charakteryzujących kobiety. Komponent cech osobowości przypisywał paniom: emocjonalność, zdolność do poświęceń, czułość, pomocność, troskliwość wobec innych. W komponencie ról społecznych kobiety postrzegane były jako osoby wspierające emocjonalnie innych oraz zarządzające domem i opiekujące się dziećmi. W ich wyglądzie zewnętrznym dominowały: wdzięk, delikatny głos, miękkość ruchów oraz schludność. Pierwszy sposób rozumienia macierzyństwa definiowany jest również poprzez subiektywne sposoby „przeżywania macierzyństwa, odgrywania 
roli matki w różnych sytuacjach i kręgach społecznych" (Bielecka-Prus, Kruk 2014, s. 82) przez same kobiety.

Macierzyńska powinność łączy się nierozerwalnie z pojęciem roli społecznej, narzucającej pewne wzorce zachowań, których wypełniania grupa społeczna oczekuje od kobiety-matki, a więc w relacji matka-dziecko można wyróżnić kilka charakterystycznych atrybutów kulturowych wzorów zachowań, a są nimi: ochrona, utrzymanie, wspieranie rozwoju fizycznego oraz kierowanie procesem edukacji i wychowania (Znaniecki 2011). Matka rozpoczyna relację z dzieckiem poprzez jego bezwarunkową akceptację, dbałość o zaspokojenie potrzeb biologicznych i psychicznych, stopniowe wdrażanie do samodzielności. Rola matki „jest rolą przypisaną względnie trwale do jednostki, odgrywaną w zróżnicowanym kręgu społecznym [...]. We współczesnych społeczeństwach role kobiet są bardzo złożone, a nadmiar obowiązków skutkuje licznymi napięciami i konfliktami ról" (Bielecka-Prus, Kruk 2014, s. 85). „Instytucjonalne” podejście do macierzyństwa pełni swego rodzaju funkcję kontroli społecznej nad prawidłowością wypełniania tej niezwykle ważnej roli życiowej i odczytywane jest niekiedy jako „wywieranie presji i skłanianie lub wręcz zmuszanie kobiet do postępowania zgodnie ze społecznymi oczekiwaniami" (Bielecka-Prus, Kruk 2014, s. 82).

Potrzeba i powinność w zakresie pełnienia roli macierzyńskiej są dwiema uzupełniającymi się rzeczywistościami, których nie należy sobie przeciwstawiać. Jedynie psychiczna i biologiczna dojrzałość do podjęcia obowiązków macierzyńskich, idąca $\mathrm{w}$ parze $\mathrm{z}$ wejściem $\mathrm{w}$ tę rolę zgodnie $\mathrm{z}$ mądrze ustanowionymi oczekiwaniami społecznymi, może gwarantować sukces w realizacji powołania do rodzenia i wychowywania dzieci. Tymczasem pojawia się szereg tez antagonizujących oba obszary, a należą do nich: sprowadzanie pojęcia instynktu macierzyńskiego do stereotypu społecznego, kwestionowanie istnienia naturalnej potrzeby posiadania potomstwa, sugestia ograniczania oczekiwań społecznych wobec kobiet do pełnienia przez nie wyłącznie ról macierzyńskich i seksualnych oraz stwarzanie presji społecznej niepozostawiającej kobietom innego wyboru poza rolą macierzyńską (Marszałek 2006; Sikorska 2009). We współczesnych czasach, za sprawą radykalnego feminizmu, toczy się wiele sporów i dyskusji wokół macierzyństwa. „Instynkt macierzyński i miłość macierzyńska zostały zakwestionowane ponownie” (Sikorska 2009, s. 172). „Macierzyństwo nie jest już współcześnie jednoznacznie kojarzone z naturą kobiety, jej misją i „przeznaczeniem” oraz wrodzonym instynktem macierzyńskim, i coraz więcej zachowań kobiet [...] jest skutkiem ich rzeczywistych wyborów" (Sikorska 2009, s. 176), które również, w sposób niekwestionowany, podlegają presji społecznej, ekonomicznej czy kulturowej. Tak dawniej, jak i dziś zdarzają się przypadki manipulowania macierzyństwem poprzez wykorzystywanie go do celów politycznych, biurokratycznych czy komercyjnych (macierzyństwo jako produkt reklamowy). Nierzadko w macierzyństwo wpisują się różne formy przemocy czy seksbiznesu. Miało ono i ma obecnie swoją ciemną 
stronę macierzyństwa nieidealnego, dalekiego od bezgranicznego oddania, troski i poświęcenia (Bartkowiak 2015).

Podważanie znaczenia tradycyjnej rodziny, duża presja na emancypację kobiet, kult sukcesu życiowego nastawionego na indywidualny rozwój, osłabienie męskiego autorytetu oraz niekorzystne w polskich warunkach względy socjoekonomiczne, mające wpływ na jakość życia rodzin sprawiają, że kształtuje się zupełnie nowa sylwetka kobiety-matki. Jej pierwszym „atrybutem”, według Małgorzaty Sikorskiej (2009), jest niepewność, która dotyczy chęci posiadania potomstwa, przebiegu ciąży i porodu oraz wydolności wychowawczej. Niepewna matka często postrzega swoje macierzyństwo przez pryzmat informacji dostępnych w środkach masowego przekazu, gdzie przedstawiane jest ono często jako niezwykle trudne zadanie, wyczerpujące, odpowiedzialne, mało prestiżowe, ograniczające kobietę w jej ambicjach. Drugą cechą współczesnej matki jest osamotnienie, spowodowane oderwaniem od rodziny wielopokoleniowej oraz migracją z małych ośrodków wiejskich i miasteczek do dużych aglomeracji, a także poza granice własnego kraju. Substytutem bliskich relacji rodzinnych staje się aktywność na forach internetowych, tworzenie relacji z osobami nieznanymi w podobnej sytuacji życiowej. Cecha trzecia to nadmierne nastawienie na porady ekspertów w zakresie pielęgnacji, wychowania i edukacji własnego potomstwa. Opisany model macierzyństwa zyskał już w literaturze przedmiotu miano „projektu menedżerskiego” (Urbańska 2009). Współczesna kobieta może realizować swoje macierzyństwo jako pani domu lub kobieta łącząca obowiązki domowe z pracą zawodową. Jest umacniana w przekonaniu, że do niej należy wybór samego macierzyństwa i sposobu jego realizacji. Jednak konsekwencją wielości wyborów jest niepewność, która skutkuje „stresem, depresją, frustracją, przekonaniem, że nie radzi sobie z macierzyństwem” (Sikorska 2009, s. 181). Można odnieść wrażenie, że warunki życia społeczeństwa ponowoczesnego, niosące takie obciążenia, jak: nadmierne tempo życia, modę na samotność, nacisk na permanentną edukację i ciągłe samodoskonalenie się, niestałość zatrudnienia oraz pokusy życia konsumpcyjnego, nie sprzyjają podejmowaniu ryzyka bycia matką, co stawia każdą współczesną kobietę w sytuacji niepełnej sprawności do wypełnienia jednej z najważniejszych ról w ich życiu.

\section{Wizerunek społeczny macierzyństwa kobiet z niepełnosprawnością}

Macierzyństwo, jako rola życiowa i społeczna, kojarzone jest ze stanem dorosłości. Zdaniem Małgorzaty Kościelskiej (2012) jest to pojęcie wieloznaczne, które można rozpatrywać na kilku płaszczyznach. Pierwszą z nich jest aspekt prawny, który ze względu na wiek życia osoby, przypisuje jej prawa wyborcze czy możliwość wejścia w związek małżeński. Wejście w dorosłość oznacza ustanie władzy rodzicielskiej. Osobie dorosłej w sensie społecznym przypisuje się określone postawy, charakteryzujące się poczuciem odpowiedzialności, dbałością o bezpieczeństwo i zdrowie, poważnym stosunkiem do obowiązków czy zaradnością 
życiową. Dojrzałość społeczna nie byłaby możliwa bez osiągnięcia dorosłości w znaczeniu psychologicznym, która charakteryzuje się zdolnością myślenia abstrakcyjnego, wielokierunkowego, umiejętnością panowania nad własnymi emocjami i zachowaniami, życiem według przyjętego i uznanego systemu wartości oraz identyfikacją w ramach określonej tożsamości. „Dorosłość jest procesem rozwojowym, ukierunkowanym na zdobywanie coraz większej autonomii i podejmowanie coraz trudniejszych zadań" (Kościelska 2012, s. 18). Podjęcie roli i zadań związanych z macierzyństwem wymaga osiągnięcia dojrzałości psychicznej, fizycznej, społecznej i prawnej jednocześnie.

Czy wymienione obszary dojrzałości mogą być całkowicie wypełnione w sytuacji przeżywanej przez osobę z niepełnosprawnością? Zdolność prawna przysługuje wszystkim osobom od momentu urodzenia. Ubezwłasnowolnieniu całkowitemu lub częściowemu może podlegać wyłącznie osoba z zaburzeniami zdrowia psychicznego lub osoba $z$ niepełnosprawnością intelektualną, jeśli przeżywane stany uniemożliwiają jej kierowanie własnym postępowaniem. Wszelkie inne niepełnosprawności nie mogą powodować częściowego lub całkowitego odebrania przysługujących osobie praw. Również stan ubezwłasnowolnienia nie dotyczy w sposób natychmiastowy osób objętych wymienionymi wcześniej zaburzeniami, tylko i wyłącznie ze względu na ich zaistnienie (Wedeł-Domeradzka 2012). Skutkiem całkowitego ubezwłasnowolnienia jest całkowity zakaz wejścia w związek małżeński, a także pozbawienie władzy rodzicielskiej osoby ubezwłasnowolnionej. Osoby ubezwłasnowolnione częściowo mogą zawrzeć ważny związek małżeński za zgodą sądu, który, zdaniem Agnieszki Wedeł-Domeradzkiej (2012), ocenia zdolność osoby do radzenia sobie w codziennych sytuacjach oraz istotnych czynnościach, mających wpływ na funkcjonowanie rodziny. Prawo do wyrażania więzi seksualnej oraz posiadania potomstwa przez osoby z różnego typu niepełnosprawnościami jest jedną z najbardziej kontrowersyjnych kwestii związanych z okresem dorosłości tych osób. Dominują dwa typy rozwiązań wskazanego problemu: liberalny - propagujący prawo do swobodnej ekspresji seksualnej, zobowiązujący opiekunów do stworzenia odpowiednich warunków w celu zaspokojenia tych potrzeb (dostęp do antykoncepcji lub warunkowe przyznanie prawa do posiadania potomstwa) oraz personalistyczny - wskazujący na integralny związek pomiędzy potrzebami uczuciowymi i społecznymi a seksualnymi człowieka, niedopuszczający do zredukowania człowieka wyłącznie do instynktownych potrzeb popędowych, proponujący wprowadzenie ładu wychowania seksualnego, którego celem jest panowanie nad potrzebami seksualnymi oraz kształtowanie zdolności do wchodzenia w trwałe związki uczuciowe (Kornas-Biela 2015). Zdecydowanie, w podejściu do seksualności osób niepełnosprawnych, dominuje model liberalny, funkcjonujący na tle tendencji eugenicznych, legalizujących aborcję dzieci z ujawnionymi wadami rozwojowymi. Ta tendencja prowadzi do podwójnej marginalizacji społecznej kobiety z niepełnosprawnością: ze względu na stan jej zdrowia oraz w dziedzinie prokreacji i życia małżeńskiego. 
Jednocześnie, ocena dojrzałości społecznej osób z niepełnosprawnością, według Stanisława Waszczaka, wypada dość niekorzystnie. Społeczeństwo często postrzega te osoby jako „niezdolne do niczego" (Waszczak 2000, s. 95), posługując się pejoratywnymi terminami: „osoba z niepełną sprawnością”, „niepełnosprawny”, „upośledzony”, „przywiązany do wózka inwalidzkiego”, „ten niewidomy”. Osoby z niepełnosprawnością często postrzegane są jako labilne emocjonalnie, introwertyczne, pesymistycznie nastawione do życia, nadmiernie skoncentrowane na sobie, zależne od najbliższego otoczenia oraz wrogo nastawione. Oceniane są jako mniej wartościowe i mniej godne uczestnictwa w życiu społecznym. Seksualność człowieka, w oparciu o funkcjonujący stereotyp, wiązana jest z młodością, atrakcyjnością i sprawnością fizyczną. Do tego stereotypu nie przystaje ogólny wizerunek osób niepełnosprawnych, w przypadku których, w dyskursie publicznym, zawieszeniu ulegają "prawo do przekazywania życia i posiadania dzieci [...], potrzeby emocjonalne i uczuciowe [...] oraz ich prawa do nawiązywania satysfakcjonujących związków społecznych" (Waszczak 200o, s. 96). Otoczenie prezentuje negatywne postawy w postaci lekceważenia, negowania, odrzucania potrzeb i zadań rozwojowych osób z niepełnosprawnością, powodując kształtowanie się negatywnego obrazu ich możliwości, ograniczając aspiracje i plany życiowe osób niepełnosprawnych oraz odbierając im nadzieję (Kornas-Biela, 2015; za: Kowalik, 1989). Antonina Ostrowska (2015, s. 150), analizując sytuację osób z niepełnosprawnością w społeczeństwie polskim na przestrzeni lat 1993-2013, zwróciła uwagę na to, iż „Modele adaptacji, integracji społecznej podkreślają rolę wykształcenia, zatrudnienia czy posiadania niezależności życiowej, jednak eliminują działania, które mogłyby pomóc w realizacji najbardziej osobistych i intymnych potrzeb” osób z niepełnosprawnością. Od lat właściwie nie zmieniła się ocena społeczna szans osób niepełnosprawnych na znalezienie współmałżonka, partnera i założenie rodziny - ponad 60 proc. badanych stwierdziło w 2013 roku, że były one mniejsze, ok. 30 proc. utrzymywało, iż kształtowały się na takim samym poziomie, jak w przypadku osób pełnosprawnych. Opinia publiczna częściej dostrzegała szanse na udane związki uczuciowe w przypadku małżeństw obydwojga partnerów niepełnosprawnych niż par mieszanych. Jednak zaskakujący był sposób charakteryzowania postawy potencjalnego małżonka z niepełnosprawnością. Według opinii osób badanych jawił się on częściej jako osoba wymagająca opieki, zrozumienia, słaba niż odpowiedzialna, wartościowa, pracowita czy spełniająca się w wielu rolach. Jednocześnie słabszym ogniwem w tandemie stosunków damsko-męskich były kobiety z niepełnoprawnością, mające dwukrotnie mniejsze szanse na perspektywę zawarcia związku małżeńskiego niż mężczyźni w podobnej sytuacji życiowej (Ostrowska 2015).

Sytuacja społeczna kobiet niepełnosprawnych w Polsce jest trudniejsza niż w przypadku mężczyzn. Niższy jest ich status materialny. Są mniej wykształcone i dwukrotnie rzadziej niż mężczyźni podejmują aktywność zawodową. Często bywają w swojej niepełnosprawności zdane wyłącznie na siebie, ponieważ samotnie 
prowadzą gospodarstwa domowe i niejednokrotnie wychowują dzieci. Bywają wycofane i niepewne, stwarzając $z$ niepełnosprawności główny aspekt własnej identyfikacji (Ostrowska 2015). Stereotypy społeczne dotyczące kobiet z niepełnosprawnością przedstawiają je jako „bierne, słabe, zależne od innych, niekompetentne, samotne i nieatrakcyjne fizycznie" (Ciaputa i in. 2014). Kobieta niepełnosprawna jest społecznie odbierana jako niesamodzielna, a więc narażona na przemoc i emocjonalne wykorzystanie.

Tradycyjnie, rola kobiety jest usytuowana również wśród obowiązków domowych. Kobiety niepełnosprawne szczególnie mocno związane są z tym środowiskiem, ponieważ rzadziej realizują swoje aspiracje zawodowe. Niepełnosprawność może utrudniać lub ograniczać im możliwość wykonania różnych koniecznych czynności domowych, co jest szczególnie dotkliwym faktem i trudną zmianą, jeśli niepełnosprawność pojawia się $\mathrm{w}$ trakcie życia. Może być także stanem nie do zniesienia $\mathrm{w}$ przypadku młodych osób dorosłych z niepełnosprawnością od urodzenia, dla których środowisko domowe staje się zamkniętą przestrzenią, w obrębie której trudno jest zrealizować aspiracje związane z marzeniem o założeniu własnej rodziny. Rodziny pochodzenia często negują owe młodzieńcze aspiracje. Ewelina Ciaputa, Agnieszka Król, Aleksandra Migalska i Marta Warat (2014) przedstawiły kilka mechanizmów społecznych zmierzających do zdeprecjonowania macierzyństwa kobiet $\mathrm{z}$ niepełnosprawnością, a należą do nich: podważanie prawa do podejmowania decyzji prokreacyjnych (tezy: ciąża jest zagrożeniem dla zdrowia i życia kobiety; jakość życia dziecka się pogarsza, gdy wychowywane jest przez osobę niepełnosprawne; decyzje prokreacyjne powinni podejmować opiekunowie), ryzyko dziedziczenia niepełnosprawności (tezy: niepełnosprawność jest postrzegana wyłącznie jako nieszczęście, które należy wyeliminować, przecinając łańcuch dziedziczenia), najważniejsze jest dobro dziecka (tezy: niepełnosprawność negatywnie przekłada się na efekty wychowawcze; dziecko wymaga opieki zastępczej). Nakręcaniu spirali krzywdzących stereotypów sprzyja niepełny i rozproszony przekaz medialny, co nie służy kształtowaniu pozytywnego obrazu opisywanej roli społecznej.

Tymczasem, „Wśród kobiet z niepełnosprawnością powszechne są nie tylko pragnienia zawarcia małżeństwa i realizacji w rodzicielstwie, ale również niepokoje dotyczące możliwości realizacji ich małżeńsko-rodzicielskich planów, zwłaszcza że napotykają na bariery społeczne w postaci uprzedzeń" (Kornas-Biela 2015, s. 19). Jednak, mimo niepełnosprawności różnego stopnia i rodzaju, kobiety niejednokrotnie dawały dowód temu, iż były w stanie sprostać zadaniom opiekuńczym i wychowawczym, znajdując twórcze rozwiązania dla trudności napotykanych na co dzień (Ciaputa i in. 2014). 


\section{Specyfika macierzyństwa kobiet z niepełnosprawnością}

Specyficzną cechą kontekstu macierzyństwa kobiet z niepełnosprawnością jest ogólnospołeczny brak akceptacji dla niego. Polskie społeczeństwo akceptuje związki małżeńskie osób niepełnosprawnych - wyjątek stanowi tu niepełnosprawność intelektualna - ale wyraźnie ogranicza swoje przyzwolenie dla posiadania potomstwa przez te pary (Izdebski 2005; Parchomiuk 2005). Opisywana tendencja zyskała w literaturze miano bariery o charakterze kulturowym (Nowak 2016) względem pełnienia ról płciowych i rodzicielskich przez osoby z niepełnosprawnością. Hasła oddające klimat nastawienia społecznego względem omawianej problematyki mogłyby brzmieć w sposób następujący: płciowość i zachowania seksualne nie idą $\mathrm{w}$ parze $\mathrm{z}$ chorobą i niepełnosprawnością, osoby niepełnosprawne są niezdolne do podejmowania ról płciowych, zachowania intymne osób niepełnosprawnych są nieprzyzwoite, a kobieta z niepełnosprawnością jest nieatrakcyjna fizycznie. Sformułowane twierdzenia urastają do rangi stereotypów tworzących bariery natury kulturowej.

Do trudności obiektywnych, nazywanych barierami infrastruktury społecznej, zaliczyć można brak dostępu do rzetelnego i systemowego przygotowania do macierzyństwa, ojcostwa oraz życia w rodzinie poprzez edukację na poziomie szkół (młodzież), organizacji społecznych (osoby dorosłe) czy placówek służby zdrowia (szkoły rodzenia z infrastrukturą i programami edukacyjnymi, a także metodami i formami pracy dostosowanymi do potrzeb osób z różnymi rodzajami niepełnosprawności) (Dmoch-Gajzlerska, Mazurkiewicz 2011). Kontynuacją wspomnianego przygotowania powinno być długofalowe wsparcie instytucjonalne dla wypełnianych przez osoby niepełnosprawne funkcji rodzicielskich (asystent rodziny) - takich rozwiązań brakuje w polskich warunkach. Kobiety niepełnosprawne odbierane są jako aseksualne (Ciaputa i in. 2014), a więc pozbawione potrzeby zdobywania informacji na temat potrzeb emocjonalno-intymnych oraz ich konsekwencji. Kolejnym utrudnieniem jest nierówny dostęp do publicznej opieki lekarskiej, zwłaszcza ginekologicznej i okołoporodowej, na poziomie barier fizycznych, proceduralnych, świadomości personelu medycznego na temat możliwości i utrudnień przeżywanych przez pacjentki oraz barier komunikacyjnych (Ciaputa $i$ in. 2014). Utrudnieniem dla racjonalnego podejmowania decyzji prokreacyjnych jest również brak stosownych uregulowań prawnych umożliwiających badania genetyczne par przygotowujących się do podjęcia decyzji o poczęciu dziecka (DmochGajzlerska, Mazurkiewicz 2011).

Trudności subiektywne dotyczą psychicznej gotowości kobiety z niepełnosprawnością do podjęcia zadań związanych z macierzyństwem. Zdaniem D. Kornas-Bieli (2015), kobiety niepełnosprawne żyją obciążone szeregiem trudności psychicznych, które utrudniają lub uniemożliwiają im wejście w trwały związek uczuciowy, zawarcie małżeństwa oraz szczęśliwe urodzenie i wychowanie dzieci. Podstawowym utrudnieniem natury psychicznej jest bariera w zakresie 
określenia własnej tożsamości przez kobietę z niepełnosprawnością (Błeszyńska 2004). Rola społeczna wynikająca z posiadania określonej płci ustępuje niejednokrotnie roli osoby niepełnosprawnej, dla której dominującymi atrybutami są zależność, poczucie słabości, bierność oraz brak zdolności kierowania własnym życiem, a także automarginalizacja i tendencja do zamykania się w kręgu osób posiadających podobne problemy. Kobiety niepełnosprawne, zwłaszcza z widoczną niepełnosprawnością, borykają się również z trudnościami w zakresie akceptacji własnych niedoskonałości cielesnych, co w kulturze afirmującej piękno i harmonię w budowie sylwetki ludzkiej urasta do problemu pierwszorzędnej wagi. Kobieta nieakceptująca siebie w pełni ma niską samoocenę, co utrudnia jej wejście w pozytywne relacje z potencjalnym partnerem (Nowak 2016) i stanowi dodatkowe obciążenie w kontekście znanej prawdy, iż „Kobietom niepełnosprawnym trudniej znaleźć partnera i najczęściej zawierają związki z niepełnosprawnymi mężczyznami” (Nowak 2016, s. 106). Kolejnym utrudnieniem jest przeświadczenie o niepełnej sprawności nie tylko w sferach fizycznej, psychicznej czy umysłowej, ale także prokreacyjnej. Kobieta niepełnosprawna za sprawą otoczenia (personel medyczny, personel pomocowy, rodzina), żyje w przeświadczeniu, iż jest niezdolna do urodzenia dziecka lub powinna się ograniczyć w sferze prokreacji. Następną przeszkodą jest irracjonalny lęk przed odrzuceniem ze strony partnera oraz obawa przed problemami życia codziennego, które pociągają za sobą założenie rodziny oraz pojawienie się dzieci. Lęk ten często wynika z doświadczeń wyniesionych $\mathrm{z}$ domu rodzinnego nazbyt często dotkniętego biedą, bezrobociem i różnymi formami wykluczenia społecznego.

Barierą na płaszczyźnie fizycznej, stanowiącą utrudnienie w podjęciu decyzji o macierzyństwie przez kobietę niepełnosprawną, jest jej własny stan zdrowia i wielość sprzecznych informacji, które napływają od lekarzy specjalistów. Niedobory w zakresie indywidualnego stanu zdrowia dotyczyć będą ograniczeń w zakresie ogólnej wydolności fizycznej (osoby chorujące przewlekle), zaburzeń sprawności sensorycznej (dysfunkcje percepcji wzrokowej czy słuchowej), ograniczeń motorycznych oraz dysfunkcji zdolności poznawczych i zdolności kierowania własnym zachowaniem. Celem poradnictwa specjalistycznego jest minimalizowanie skutków niepełnosprawności w sferze fizycznej. Niejasność napływających komunikatów, brak pewności co do trafności prognoz, wreszcie sprzeczności pomiędzy diagnozami sprawiają jednak, że świadome podjęcie trafnej decyzji w kwestii urodzenia dziecka staje się bardzo trudne, dodatkowo bezlitośnie podważana jest taka decyzja przez opinie najbliższego otoczenia. Profilaktyka przebiegu ciąży jest również zadaniem trudniejszym do zrealizowania w przypadku kobiet niepełnosprawnych. Regularny kontakt $z$ lekarzem prowadzącym, służący zdrowiu matki i dziecka, bywa niemożliwy ze względu na bariery architektoniczne czy komunikacyjne, a także brak przygotowania personelu medycznego do rozumienia potrzeb i oczekiwań osób z różnymi rodzajami niepełnosprawności: wzrokową, słuchową, ruchową czy intelektualną. 
Kobietom niepełnosprawnym przyznaje się „prawo do pełnego uczestnictwa w życiu społecznym, respektowane jest ich prawo do życia seksualnego" (Kornas-Biela 2015, s. 27), ale brakuje im wsparcia w zakresie przygotowania do podjęcia obowiązków rodzicielskich oraz niedostateczny jest ich dostęp do opieki ginekologicznej, co utrudnia podjęcie tej podstawowej dla kobiety roli życiowej. Wejście w związek małżeński i podjęcie ról rodzicielskich ma dla osób niepełnosprawnych niebagatelne znaczenie w kwestii rehabilitacji psychicznej i społecznej. Pozytywna zmiana sytuacji życiowej, poczucie, że człowiek kocha, jest kochany i ma szansę stworzyć nową, lepszą i niepowtarzalną jakość w postaci pełnej rodziny stwarza poczucie odrodzenia. Osoba odczuwa chęć do życia, zdobywa motywację do realizacji zadań ważnych życiowo, dąży do osiągania nowych kwalifikacji i umiejętności, dba o siebie i własne zdrowie. Dojrzewa, usamodzielnia się, uniezależnia od rodziny - daje początek nowemu życiu.

\section{Podsumowanie}

Naturalnym miejscem życia człowieka jest rodzina, jako środowisko rodzenia, edukacji i wychowania dzieci, opieki i wsparcia, podstawa budowania tożsamości i przynależności społecznej oraz narodowej. Dla osób z niepełnosprawnością rodzina pochodzenia jest podstawowym środowiskiem wsparcia, ponieważ osoby te „często nie zakładają własnej rodziny” (Ostrowska 2015, s. 164). Obiektywne przyczyny takiego stanu rzeczy wymagają zbadania, usystematyzowania i opisania, gdyż istotna rola rodziny własnej w procesie osiągania maksymalnych efektów kompleksowej rehabilitacji jest zdecydowanie niedoceniana i nie zajmuje istotnego miejsca w teoretycznych modelach integracji społecznej opisywanej grupy osób. Istotna wydaje się systematyczna praca nad zmianą niekorzystnego wizerunku społecznego rodziny, macierzyństwa i ojcostwa osób z niepełnosprawnością poprzez: podejmowanie badań $\mathrm{w}$ zakresie pedagogiki specjalnej i dziedzin pokrewnych nad stanem i specyfiką życia rodzinnego, macierzyństwa i ojcostwa osób z niepełnosprawnością w Polsce, a także ich potrzebami natury fizycznej, psychicznej, społecznej, kulturowej, infrastrukturalnej i ekonomicznej, których zaspokojenie wydaje się być istotne dla godnego wypełniania podjętych przez te osoby ról oraz tworzenie nowych rozwiązań praktycznych, które wspomogą młode osoby niepełnosprawne i ich własne rodziny i przyczynią się do dobrej zmiany w opisywanym zakresie.

Założenie rodziny, urodzenie i wychowanie potomstwa przez kobietę obciążoną niepełnosprawnością jest zadaniem trudnym, odpowiedzialnym, ale możliwym do zrealizowania. Tak jak każde przedsięwzięcie wymaga wcześniejszego przemyślenia, przygotowania i konsekwentnej realizacji mimo pojawiających się trudności różnorakiej natury. Osobę decydującą się na ten krok powinna cechować pełna gotowość do podjęcia zarówno ról małżeńskich, jak i rodzicielskich, obiektywizm w ocenie własnych możliwości i deficytów oraz krytyczna ocena własnej sytuacji związanej z poziomem dojrzałości społecznej, adekwatnością wykształcenia do 
potrzeb rynku pracy, posiadanym źródłem utrzymania oraz warunkami mieszkaniowymi. Rodzina jest wspólnotą, która najskuteczniej chroni przed sytuacją wykluczenia społecznego, a jest ono rzeczywistością szczególnie zagrażającą kobietom niepełnosprawnym. Osobami wspierającymi są głównie członkowie najbliższej rodziny - rodzice, współmałżonkowie, dzieci. Rodzina jest miejscem opieki, a jej członkowie pomagają sobie nawzajem w prowadzeniu gospodarstwa domowego, wspierają się psychicznie, fizycznie, ułatwiają niepełnosprawnemu członkowi rodziny kontakt z szerszym otoczeniem społecznym. Pomoc rodziny jest skutecznym i najłatwiej dostępnym źródłem wsparcia, które nie pociąga za sobą zobowiązań finansowych (Nowak 2013). Na pomoc bliskich można przeważnie liczyć, a więc rodzina stanowi najcenniejsze wsparcie, jakie kobieta z niepełnosprawnością może sobie ofiarować.

\section{Bibliografia}

Bartkowiak E. (2015). Obraz matki i macierzyństwa w przekazach źródłowych z historii wychowania. „Wychowanie w Rodzinie”, t. XII, nr 2, s. 271-294.

Bielecka-Prus J., Kruk M. (2014). Konstruowanie roli społecznej matki w pierwszych latach życia dziecka. Analiza narracji kobiet. W: Jabłoński A., Szyszka M., Gizicka D. (red.). Współczesna rodzina polska - przemiany, zagrożenia i wyzwania. Lublin: Wydawnictwo KUL.

Błeszyńska K. (2004). Wychowanie seksualne jako element rehabilitacji osób niepełnosprawnych. W: Rzepka J. (red.). Erotyzm osób niepełnosprawnych. Mysłowice: Wydawnictwo Górnośląskiej Wyższej Szkoły Pedagogicznej im. A. Hlonda.

Ciaputa E., Król A., Migalska A., Warat M. (2014). Macierzyństwo kobiet z niepełnosprawnościami ruchu, wzroku i słuchu. „Studia Socjologiczne”, nr 2, s. 203-224.

Dmoch-Gajzlerska E., Mazurkiewicz B. (2011). Przygotowanie kobiet niepetnosprawnych do prokreacji i macierzyństwa. „Niepełnosprawność i Rehabilitacja”, nr 4, s. 93-98.

Dubisz S. (red.). (2003). Uniwersalny słownik języka polskiego, t. 3. Warszawa: Wydawnictwo Naukowe PWN.

Górnikowska-Zwolak E. (2004). Macierzyństwo. W: Różycka E. (red.). Encyklopedia pedagogiczna XXI wieku, t. 3. Warszawa: Wydawnictwo Akademickie „Żak”.

Gromkowska-Melosik A. (2013). Kobieta epoki wiktoriańskiej. Tożsamość, ciało, medykalizacja. Kraków: Oficyna Wydawnicza „Impuls”.

Izdebski Z. (2005). Postawy Polaków wobec seksualności osób niepełnosprawnych ruchowo i intelektualnie. W: Głodkowska J., Giryński A. (red.). Seksualność osób $z$ niepetnosprawnościa intelektualna - uwalnianie od schematów i uprzedzeń. Warszawa: Wydawnictwo Akademii Pedagogiki Specjalnej.

Karczewska A. (2010). Obraz ról społecznych kobiet w mediach - fikcja czy rzeczywistość. W: Muszyński W. (red.). Wartości kulturowe w rodzinie: założenia, realia i egzemplifikacje. Toruń: Wydawnictwo Adam Marszałek. 
Kornas-Biela D. (2015). Postawy społeczne wobec małżeństwa i macierzyństwa kobiet z niepetnosprawnością. W: Janocha W., Zielińska-Król K. (red.). Kobiecość a niepetnosprawność. Lublin: Wydawnictwo KUL.

Kościelska M. (2012). Przeżywanie własnej i cudzej dorosłości przez osoby z niepełnosprawnościa. W: Kijak R. J. (red.). Niepetnosprawność - w zwierciadle dorosłości. Kraków: Oficyna Wydawnicza „Impuls”.

Kowalski S. (1986). Socjologia wychowania w zarysie. Warszawa: Wydawnictwo Naukowe PWN.

Marszałek L. (2006). Niepetnosprawność-kobiecość-rodzina. Warszawa: Wydawnictwo Naukowe Uniwersytetu Kardynała Stefana Wyszyńskiego.

Nowak A. (2016). Specyfika ról pełnionych przez kobiety z niepełnosprawnością. „Praca Socjalna”, nr 1, s. 97-112.

Nowak A. (2013). Działania na rzecz kobiet z niepełnosprawnościa. „Niepełnosprawność i Rehabilitacja”, nr 2, s. 12-23.

Ostrowska A. (2015). Niepełnosprawni w społeczeństwie 1993-2013. Warszawa: Wydawnictwo Instytutu Filozofii i Socjologii PAN.

Parchomiuk M. (2005). Dorosłość osób z upośledzeniem umysłowym - wybrane aspekty. „Niepełnosprawność i Rehabilitacja”, nr 4, s. 3-19.

Sikorska M. (2009). Nowa matka, nowy ojciec, nowe dziecko. O nowym układzie sit $w$ polskich rodzinach. Warszawa: Wydawnictwa Akademickie i Profesjonalne.

Urbańska S. (2009). Profesjonalizacja macierzyństwa jako proces odpodmiotowienia matki. Analiza dyskursów poradnika "Twoje Dziecko" z 2003 i 1975 roku. W: Budrowska B. (red.). Kobiety, feminizm, demokracja. Warszawa: Wydawnictwo IFiS PAN.

Waszczak S. (2000). Stosunek społeczeństwa do osób niepełnosprawnych. „Problemy Polityki Społecznej", nr 2, s. 89-99.

Wedeł-Domeradzka A. (2012). Dorosłość osób niepełnosprawnych-aspekt prawny. W: Kijak R. J. (red.). Niepetnosprawność - w zwierciadle dorosłości. Kraków: Oficyna Wydawnicza „Impuls”.

Wołowicz-Ruszkowska A. (2013). Zanikanie? Trajektorie tożsamości kobiet z niepełnosprawnością. Warszawa: Wydawnictwo Akademii Pedagogiki Specjalnej.

Znaniecki F. (2011). Relacje społeczne i role społeczne. Warszawa: Wydawnictwo Naukowe PWN.

\section{THE SOCIAL IMAGE OF DISABLED WOMEN'S MOTHERHOOD}

Abstract: The aim of the article is to present motherhood as a social role of women with disabilities. In the article's introduction the author defines such concepts as social role, social relationships, social system and describes the mechanism of cultural patterning. The first part of the article refers to motherhood as a fundamental social role of women. 
It is presented from the historical and post-modern trends perspective, at the same time taking into consideration the needs and obligations socially associated with that role. The second part deals with the social image of the motherhood of women with disabilities; the third section describes the physical, psychological, cultural and infrastructure barriers which make the decision to become a mother difficult for women with disabilities. The summary of the report demonstrates a positive rehabilitating presence of family and motherhood in the lives of women with disabilities.

Keywords: motherhood, social role, woman with a disability.

Magdalena Wałachowska - doktor, tyflopedagog, adiunkt w Zakładzie Podstaw Pedagogiki Specjalnej Akademii Pedagogiki Specjalnej im. Marii Grzegorzewskiej w Warszawie. Zainteresowania naukowo-badawcze autorki dotyczą: analizy funkcjonowania organizacji społecznych działających na rzecz osób niewidomych i słabowidzących oraz współczesnych kierunków rehabilitacji i wsparcia pedagogiczno-społecznego osób z niepełnosprawnością wzrokową. Adres e-mailowy: magdartur@poczta.onet.pl. 